\title{
EFEKTIVITAS DAUN JERUK PURUT (CITRUS HYSTRIX) PADA APLIKASI MAT ELEKTRIK DALAM MEMBUNUH NYAMUK CULEX SP.
}

\author{
Cecep Dani Sucipto ${ }^{1)}$, Kadar Kuswandi ${ }^{2)}$
}

\begin{abstract}
Abstrak
Penyakit tular vektor khususnya yang ditularkan oleh nyamuk di Indonesia masih tinggi seperti malaria, DBD, JE, chikungunya, Filariasis, dll. Pengendalian vektor yang paling efektif dan popular di masyarakat adalah penggunaan insektisida,.salah satu yang diminati masyarakat penggunaan mat elektrik. Tujuan dalam penelitian ini adalah untuk mengetahui efektivitas daun jeruk purut (Citrus hystrix) pada aplikasi mat elektrik dalam membunuh nyamuk Culex sp. Jenis penelitian bersifat eksperimen dengan desain penelitian one group post test design with control dimana kelompok perlakuan yaitu kelompok yang diberi ekstrak daun jeruk purut dengan variasi konsentrasi yang berbeda dan diamati efek kematian pada nyamuk Culex $s p$ dewasa dibandingkan dengan kelompok kontrol. Data hasil penelitian dianalis menggunakan uji beda means ANOVA dengan alfa 5. Berdasarkan analisa data dan pembahasan dapat disimpulkan rerata kematian nyamuk semakin tinggi sesuai dengan meningkatnya konsentrasi obat yang diberikan; dengan rerata kematian nyamuk tertinggi (15.00) terdapat pada konsentrasi $1.0 \mathrm{ml}$. Terdapat perbedaan rerata kematian nyamuk yang signifikan pada masing-masing konsentrasi perasan daun jeruk purut. Ada perbedaan tingkatan konsentrasi yang diujikan memberikan efek perbedaan rerata yang signifikan terhadap kematian nyamuk.
\end{abstract}

Kata Kunci : Efektivitas daun jeruk purut, Mat elektrik, Nyamuk Culex sp

*) Dosen jurusan Analis Kesehatan Poltekkes Kemenkes Banten

**) Dosen Jurusan Kebidanan Poltekkes Kemenkes Banten 


\section{Pendahuluan}

Di Indonesia saat ini bahan anti nyamuk yang menggunakan bahan kimia sintetik dengan berbagai aplikasi penggunaannya, kandungan bahan kimia yang terkandung di dalam pestisida kimiawi sintetik dapat mengganggu kesehatan. Hal itu dibuktikan dalam penelitian yang dilakukan Indonesian Pharmaceutical Watch (IPhW) pada 2001.

Menurut penelitian yang dilakukan lembaga ini dikatakan bahwa kandungan senyawa kimia berbahaya bagi kesehatan manusia dalam seluruh obat anti nyamuk yang beredar di pasaran dalam negeri. Baik berupa obat semprot, elektrik, bakar, maupun cair yaitu: diklorvos, propoxuran dan beberapa jenis pyrethroid berupa $d$ allethrin, transflutrin, bioallethrin, pallethrin, d-phenothrin, serta esbiothrin. Bahaya dari senyawa kimia di atas telah dibuktikan oleh lembaga-lembaga kesehatan internasional. Akibat dari senyawa kimia di atas akan terbukti ketika terakumulasi dalam tubuh atau konsentrasinya melebihi ambang batas toleransi tubuh maka dapat merusak sistem saraf bahkan berpotensi menyebabkan kanker. $^{11}$

Upaya menghindari dampak negative penggunaan bahan anti nyamuk yaitu pengunaan tumbuhan sebagai bahan insektisida alami yang relative ramah lingkungan. Syarat utama penggunaan tumbuhan harus mengandung berbagai senyawa yang memiliki fungsi sebagai insektisida diantaranya golongan sianida, saponin, tanin, flavonoid, alkaloid, steroid dan minyak atsiri. ${ }^{2}$ Salah satu jenis tumbuhan yang memiliki kandungan bahan anti nyamuk adalah jeruk purut (Citrus hystrix). Berdasarkan hasil penelitian sebelumnya dilaporkan bahwa daun jeruk purut mengandung flavonoid dan atsiri ${ }^{4}$

Daun jeruk dapat berpotensi menjadi insektisida alami yang tidak membahayakan kesehatan karena mengandung minyak atsiri dengan komponen limonene, mirsen, linalool, oktanal, decanal, sitronelol, neral, geraniol, valensen, sinnsial dan sinensial,Linalol, citronellal dan geraniol termasuk senyawa yang bersifat insektisida terhadap artropoda. Daun jeruk dapat langsung dengan mudah diaplikasikan dengan membuat ekstrak sederhana yang direndam menggunakan aquades dan penyaringan. $^{2,4}$

Di era saat ini segala sesuatunya semakin berkembang, untuk itu kita dintuntut untuk berinovasi dalam memperoleh bahan yang eco save atau ramah lingkungan. Karena hal tersebut dibuatlah suatu inovasi baru dalam pembuatan obat nyamuk elektrik yang 
berbahan alami.Pada penelitian ini daun jeruk purut sebagai bahan mat elektrik agar lebih mudah diaplikasikan. Tujuan umum dalam penelitian ini adalah untuk memanfaatkan daun jeruk purut (Citrus hystrix) pada aplikasi mat elektrik dalam membunuh nyamuk Culex sp.

\section{Metode}

Rancangan penelitian yang digunakan dalam penelitian ini adalah Rancangan Acak Lengkap (RAL). Pada umumnya rancangan ini digunakan untuk kondisi lingkungan, alat, bahan dan media yang homogen, percobaan ini dilakukan dengan menggunakan 6 variasi dosis daun jeruk purut yang berbeda termasuk kontrol dengan 4 kali pengulangan. Populasi berasal dari jentik Culex sp. yang sudah di kolonisasi menjadi nyamuk dewasa yang ada di daerah Tangerang.Sampel yang digunakan adalah nyamuk Culex sp. dengan menggunakan ekstrak daun jeruk purut (Citrus hystrix) dengan 6 variasi dosis.

\section{Hasil}

\section{Pengukuran Suhu}

Suhu ruangan merupakan variabel penting yang mempengaruhi penelitian. Oleh sebab itu, pengukuran suhu perlu dilaksanakan selama berlangsungnya penelitian. Suhu ruangan diukur dengan menggunakan thermometer yang dipantau setiap hari nya pada pagi, sore, dan malam yang di catat dalam tabel sehingga diperoleh hasil pengukuran yakni pada ulangan I adalah $27^{\circ} \mathrm{C}$, ulangan II adalah $27^{\circ} \mathrm{C}$, ulangan III adalah $28^{\circ} \mathrm{C}$ dan rata-rata suhu ruangan penelitian adalah $27,33^{\circ} \mathrm{C}$ dengan suhu tertinggi $30,2{ }^{\circ} \mathrm{C}$ dan suhu terendah $25,1^{\circ} \mathrm{C}$.

2. Pengukuran Kelembapan

Kelembaban merupakan salah satu variabel yang dihitung dalam penelitian ini. Kelembaban diukur dengan menggunakan hygrometer yang dipantau setiap hari nya pada pagi, sore, dan malam yang di catat dalam tabel sehingga didapatkan hasil yaitu kelembaban pada pengulangan I sebesar 65\%, pada pengulangan II sebesar $62,5 \%$, pada pengulangan III sebesar $70 \%$, maka ratarata kelembaban ruangan penelitian tersebut yaitu sekitar $65,83 \%$ dengan kelembapan tertinggi $70 \%$ dan terendah $47 \%$.

\section{Kematian Nyamuk Uji}

Kematian Nyamuk Culex Setelah Pemaparan Mat Elektrik Berbahan Aktif Jeruk Purut

\begin{tabular}{|c|c|c|c|c|}
\hline \multirow{2}{*}{ Replikasi } & \multicolumn{3}{|c|}{ Dosis } & \multirow{2}{*}{ Kontrol } \\
\cline { 2 - 5 } & $\begin{array}{c}\mathbf{0 , 5} \\
\mathbf{~ m l}\end{array}$ & $\mathbf{0 , 7 5} \mathbf{~ m l}$ & $\mathbf{1} \mathbf{~ m l}$ & \\
\hline $\mathbf{1}$ & 10 & 15 & 15 & 1 \\
$\mathbf{2}$ & 10 & 14 & 15 & 1 \\
$\mathbf{3}$ & 11 & 14 & 15 & 2 \\
$\mathbf{4}$ & 10 & 14 & 15 & 1 \\
$\mathbf{5}$ & 10 & 15 & 15 & 1 \\
$\mathbf{6}$ & 10 & 15 & 15 & 2 \\
$\mathbf{7}$ & 11 & 14 & 15 & 2 \\
$\mathbf{8}$ & 9 & 14 & 15 & 1 \\
$\mathbf{9}$ & 10 & 15 & 15 & 1 \\
\hline Rata-rata & 10,11 & 14,44 & 15,00 & 1,33 \\
Kematian & & & \multicolumn{3}{|c}{} \\
\hline
\end{tabular}


Pada tabel 1 menunjukkan bahwa ada peningkatan kematian dari setiap berat daun jeruk purut untuk setiap 6 jam pengamatan. Kematian tertinggi terjadi pada jam ke-24 dengan berat mat $1 \mathrm{ml}$ sebanyak 15 ekor di pengulangan kedua dan ketiga.

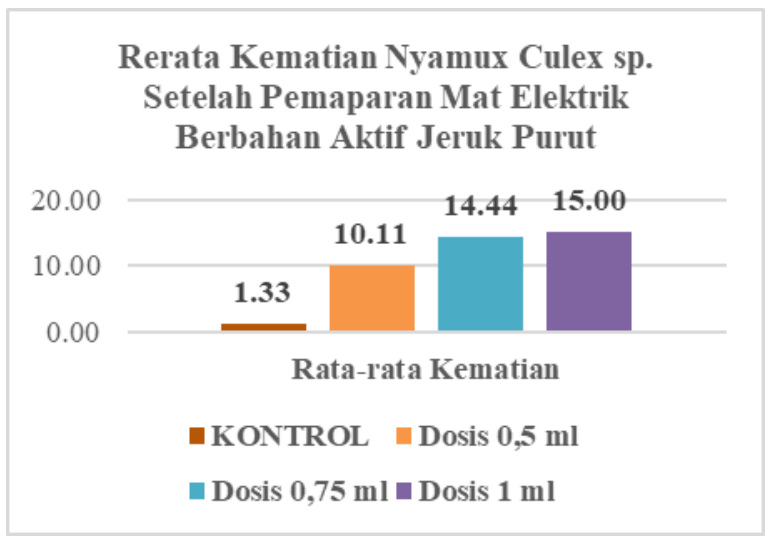

Grafik di atas menunjukkan bahwa kematian pada konsentrasi $0,5 \mathrm{ml}$ pada jam ke-24 sebesar $64,74 \%$ dan dikatakan bahwa ekstrak daun jeruk purut efektif dalam membunuh nyamuk Culex $s p$. dengan presentase sebesar $100 \%$ pada dosis $1 \mathrm{ml}$ selama 24 jam pengamata. Selanjutnya data hasil penelitian dilakukan uji Anova untuk mengetahuan perbedaan perlakukan pada masing-masing konsentrasi, adapun hasilnya seperti pada tabel dibawah ini:

Kmtian

\section{Descriptives}

\begin{tabular}{|c|c|c|c|c|c|c|c|c|}
\hline & \multirow[t]{2}{*}{$\mathrm{N}$} & \multirow[t]{2}{*}{ Mean } & \multirow[t]{2}{*}{$\begin{array}{c}\text { Std. } \\
\text { Deviation }\end{array}$} & \multirow[t]{2}{*}{$\begin{array}{l}\text { Std. } \\
\text { Error }\end{array}$} & \multicolumn{2}{|c|}{$\begin{array}{l}\text { 95\% Confidence } \\
\text { Interval for Mean }\end{array}$} & \multirow[t]{2}{*}{ Minimum } & \multirow[t]{2}{*}{ Maximum } \\
\hline & & & & & $\begin{array}{l}\text { Lower } \\
\text { Bound }\end{array}$ & $\begin{array}{l}\text { Upper } \\
\text { Bound }\end{array}$ & & \\
\hline $0.5 \mathrm{ml}$ & 9 & 10.11 & .601 & .200 & 9.65 & 10.57 & 9 & 11 \\
\hline $0.75 \mathrm{ml}$ & 9 & 14.33 & .500 & .167 & 13.95 & 14.72 & 14 & 15 \\
\hline $1 \mathrm{ml}$ & 9 & 15.00 & .000 & .000 & 15.00 & 15.00 & 15 & 15 \\
\hline Control & 9 & 1.33 & .500 & .167 & .95 & 1.72 & 1 & 2 \\
\hline Total & 36 & 10.19 & 5.544 & .924 & 8.32 & 12.07 & 1 & 15 \\
\hline
\end{tabular}

ANOVA

Kmtian

\begin{tabular}{|c|c|c|c|c|c|}
\hline & Sum of Squares & Df & Mean Square & F & Sig. \\
\hline Between Groups & 1068.750 & 3 & 356.250 & 1654.839 & .000 \\
Within Groups & 6.889 & 32 & .215 & & \\
Total & 1075.639 & 35 & & & \\
\hline
\end{tabular}


Dependent Variable: kmtian

\section{Multiple Comparisons}

Bonferroni

\begin{tabular}{|c|c|c|c|c|c|c|}
\hline \multirow{2}{*}{$\begin{array}{l}\text { (I) } \\
\text { konsentrasi }\end{array}$} & \multirow{2}{*}{$\begin{array}{l}(\mathrm{J}) \\
\text { konsentrasi }\end{array}$} & \multirow{2}{*}{$\begin{array}{c}\text { Mean } \\
\text { Difference } \\
(\mathrm{I}-\mathrm{J})\end{array}$} & \multirow[t]{2}{*}{ Std. Error } & \multirow[t]{2}{*}{ Sig. } & \multicolumn{2}{|c|}{ 95\% Confidence Interval } \\
\hline & & & & & Lower Bound & $\begin{array}{l}\text { Upper } \\
\text { Bound }\end{array}$ \\
\hline \multirow{4}{*}{$0.5 \mathrm{ml}$} & $0.75 \mathrm{ml}$ & $-4.222^{*}$ & .219 & .000 & -4.84 & -3.61 \\
\hline & $1 \mathrm{ml}$ & $-4.889^{*}$ & .219 & .000 & -5.50 & -4.27 \\
\hline & kontrol & $8.778^{*}$ & .219 & .000 & 8.16 & 9.39 \\
\hline & $0.5 \mathrm{ml}$ & $4.222^{*}$ & .219 & .000 & 3.61 & 4.84 \\
\hline \multirow[t]{3}{*}{$0.75 \mathrm{ml}$} & $1 \mathrm{ml}$ & $-.667^{*}$ & .219 & .028 & -1.28 & -.05 \\
\hline & kontrol & $13.000^{*}$ & .219 & .000 & 12.38 & 13.62 \\
\hline & $0.5 \mathrm{ml}$ & $4.889^{*}$ & .219 & .000 & 4.27 & 5.50 \\
\hline \multirow[t]{3}{*}{$1 \mathrm{ml}$} & $0.75 \mathrm{ml}$ & $.667^{*}$ & .219 & .028 & .05 & 1.28 \\
\hline & kontrol & $13.667^{*}$ & .219 & .000 & 13.05 & 14.28 \\
\hline & $0.5 \mathrm{ml}$ & $-8.778^{*}$ & .219 & .000 & -9.39 & -8.16 \\
\hline \multirow[t]{2}{*}{ Control } & $0.75 \mathrm{ml}$ & $-13.000^{*}$ & .219 & .000 & -13.62 & -12.38 \\
\hline & $1 \mathrm{ml}$ & $-13.667^{*}$ & .219 & .000 & -14.28 & -13.05 \\
\hline
\end{tabular}

*. The mean difference is significant at the 0.05 level.

Setelah melakukan pengujian mat elektrik berbahan perasan daun jerut purut, terhadap nyamuk dewasa Culex sp dengan waktu kontak 1 jam dan dilakukan holding selama 24 jam, data yang diperoleh kemudian diolah dengan statistik dengan uji Anova dengan aplikasi SPSS dengan hasil sebagai berikut:

Tabel 1

Rerata Kematian Nyamuk Berdasarkan Konsentrasi Obat Dan Nilai Kemaknaan Uji

\begin{tabular}{|c|c|c|c|c|c|}
\hline \multirow[t]{2}{*}{$\mathrm{NO}$} & \multirow[t]{2}{*}{$\begin{array}{c}\text { Konsentrasi } \\
\text { Obat }\end{array}$} & \multirow[t]{2}{*}{$\begin{array}{l}\text { Rata-Rata } \\
\text { Kematian }\end{array}$} & & \multicolumn{2}{|c|}{$\begin{array}{c}\text { Hasil } \\
\text { Uji Post Hoc }\end{array}$} \\
\hline & & & & Uji Antar Konsentrasi & Nilai $p$ \\
\hline 1 & Kontrol & 1.33 & \multirow{4}{*}{0.000} & Kontrol * $0.5 \mathrm{ml}$ & 0.000 \\
\hline 2 & $0.5 \mathrm{ml}$ & 10.11 & & Kontrol $* 0.75 \mathrm{ml}$ & 0.000 \\
\hline 3 & $0.75 \mathrm{ml}$ & 14.33 & & Kontrol * $1.0 \mathrm{ml}$ & 0.000 \\
\hline \multirow[t]{3}{*}{4} & $1.0 \mathrm{ml}$ & 15.00 & & $0.5 \mathrm{ml} * 0.75 \mathrm{ml}$ & 0.000 \\
\hline & & & & $0.5 \mathrm{ml} * 1.0 \mathrm{ml}$ & 0.000 \\
\hline & & & & $0.75 \mathrm{ml} * 1.0 \mathrm{ml}$ & 0.000 \\
\hline
\end{tabular}

Secara deskriptif table 1 menunjukkan bahwa rerata kematian nyamuk semakin tinggi sesuai dengan meningkatnya konsentrasi obat yang diberikan; dengan rerata kematian nyamuk tertinggi (15.00) terdapat pada konsentrasi obat $1.0 \mathrm{ml}$.
Secara bivariat diperoleh nilai $\mathrm{p}=0.000(\mathrm{p}$ $<\alpha$ ), yang berarti bahwa H0 ditolak; dengan kata lain bahwa terdapat perbedaan rerata kematian nyamuk yang signifikan pada masing-masing konsentrasi perasan daun jeruk purut. 
Dari hasil uji lanjutan (post hoc test) diperoleh nilai $\mathrm{p}$ seluruhnya sebesar 0.000 $(p<\alpha)$, yang berarti bahwa H0 ditolak pada seluruh hasil uji antar konsentrasi obat; dengan kata lain bahwa perbedaan tingkatan konsentrasi yang diujikan memberikan efek perbedaan rerata yang signifikan terhadap kematian nyamuk.

\section{Pembahasan}

\section{Suhu}

Suhu ruangan merupakan variabel penting yang mempengaruhi penelitian. Oleh sebab itu, pengukuran suhu perlu dilaksanakan selama berlangsungnya penelitian. Suhu ruangan diukur dengan menggunakan thermometer yang dipantau setiap hari nya pada pagi, sore, dan malam yang di catat dalam tabel sehingga diperoleh hasil pengukuran yakni pada ulangan I adalah $27^{\circ} \mathrm{C}$, ulangan II adalah $27^{\circ} \mathrm{C}$, ulangan III adalah $28^{\circ} \mathrm{C}$ dan rata-rata suhu ruangan penelitian adalah $27,33^{\circ} \mathrm{C}$ dengan suhu tertinggi $30,2^{\circ} \mathrm{C}$ dan suhu terendah $25,1^{\circ} \mathrm{C}$. Menurut Susanna dan Sembiring pada 2011 dan DepKes RI pada 2008dijelaskan bahwa rata-rata suhu optimum pertumbuhan nyamuk adalah 25 $27^{\circ} \mathrm{C} .{ }^{7,15} \mathrm{Suhu}$ penelitian pernah mencapai $30,2^{\circ} \mathrm{C}$, namun suhu ini masih mendukung sebab dalam penelitian Setyaningrum (2008) suhu yang digunakan berkisar antara $32-33,5^{\circ} \mathrm{C},{ }^{16}$ dikatakan suhu tidak mendukung hanya jika suhu diatas $35^{\circ} \mathrm{C}$ karena dapat mengalami perubahan dan lambatnya proses fisiologi, dan pertumbuhannyamuk akan terhenti pada suhu kurang dari $10^{\circ} \mathrm{C}$ atau diatas $40^{\circ} \mathrm{C}$ serta nyamukmempunyai toleransi suhu berkisar $5^{\circ} \mathrm{C}-6^{\circ} \mathrm{C}$.Berdasarkan hal tersebut dapatdinyatakan bahwa suhu pada penelitian ini masih mendukung untuk pertumbuhan danperkembangan nyamuk Culex sp.

\section{Kelembapan}

Kelembaban merupakan salah satu variabel yang dihitung dalam penelitian ini. Kelembaban diukur dengan menggunakan hygrometer yang dipantau setiap hari nya pada pagi, sore, dan malam yang di catat dalam tabel sehingga didapatkan hasil yaitu kelembaban pada pengulangan I sebesar $65 \%$, pada pengulangan II sebesar $62,5 \%$, pada pengulangan III sebesar $70 \%$, maka ratarata kelembaban ruangan penelitian tersebut yaitu sekitar $65,83 \%$ dengan kelembapan tertinggi $70 \%$ dan terendah 47\%. Menurut Jumar pada 2000, kelembaban yang mendukung pertumbuhan dan perkembangan nyamuk adalah 60\%-89\%, sehingga kelembaban ruangan pada saat percobaan tidak mengganggu. ${ }^{6}$ Pada kelembaban kurang dari $60 \%$ umur nyamuk akan menjadi pendek, tidak bisa menjadi vektor, tidak cukup waktu untuk perpindahanvirus dari lambung ke kelenjar ludah. ${ }^{8}$

Pada berat $0 \mathrm{mg}$ (kontrol) selama 24 jam di pengulangan ketiga terdapat 1 ekor nyamuk Culex sp.yang mati. Setelah di teliti penyebab kematian nyamuk pada waktu pengamatan 24 jam di pengulangan III karena kelembapan ruang penelitian yang tidak sesuai yaitu 44\%. Pada kelembaban kurang dari $60 \%$ umur nyamuk akan menjadi pendek, tidak bisa menjadi vektor, tidak cukup waktu untuk perpindahan virus dari lambung ke kelenjar ${ }^{1}$. Adaptasi pada kelembaban yang tinggi juga dapat menyebabkan nyamuk cepat lelah. $^{2}$ 
3. Pengaruh Mat Daun Jeruk Purut

Terhadap Kematian Nyamuk Culex sp.

Uji efektivitas daun tanaman jeruk purut (Cytrus hystrix) sebagai anti nyamuk elektrik dalam membunuh nyamuk Culex sp.menggunakan berbagai konsentrasi daun jeruk purut dengan 6 kali pengulangan selama 24 jam dengan interval waktu 6 jam sehingga diperoleh jumlah nyamuk Culex sp.yang mati berbeda-beda dari setiap berat dan pengulangan. Pada tabel 1 terlihat bahwa pada berat $0 \mathrm{mg}$ mat berisikertas tisu yang hanya ditetesi dengan air ditemukan hanya 1 sapai 2 ekor yang mati. Hal ini terjadi karena terjadi keleahan pada nyamuk nsaat di holding selama 24 jam. namun, pada mat yang diisi dengan serbuk daun jeruk purut menyebabkan kematian nyamuk Culex sp. Minyak atsiri daun jeruk purut memiliki kandungan senyawa yang mudah menguap dan senyawa alelokimia seperti terpenoid, tannin yang akan menyebabkan laju metabolisme nyamuk menurun ${ }^{17}$, sedangkan kertas tisu tidak menjadi penghambat dalam proses penguapan aroma daun jeruk purut karena senyawa saponin pada daun jeruk purut dapat menaikkan permeabilitas kertas saring. Filter yang cukup kecil untuk menahan partikel dengan ukuran tertentu dapat meloloskan partikel tersebut. ${ }^{9}$

Daun tanaman jeruk purut dapat dimanfaatkan sebagai mat elektrik yang dapat membunuh nyamuk Culex sp. Hal ini disebabkan oleh kandungan senyawa kimia daun jeruk purut yaitu minyak atsiridengan komponen limonene, mirsen, linalool, oktanal, decanal, sitronelol, neral, geraniol, valensen, sinnsial dan sinensial,Linalol, citronellal dan geraniol termasuksenyawa yang bersifat insektisida terhadap artropoda. ${ }^{16 \text { (dibab2) }}$

Menurut Standar WHO serta Badan Penelitian dan Pengembangan Kesehatan dikatakan efektif apabila kematian nyamuk lebih dari $70 \% .{ }^{4,18} \mathrm{Hal}$ ini di dukung penelitian yang dilakukan Zumrotus Sholichah, dkk pada 2010 menyatakan insektisida berbahanaktif Cypermethrin 15,0 ìg ai/strip yang digunakan dengan metode LO dalam penelitian ini tidak efektif karena tidak mampu membunuh nyamuk uji $\geq 70 \%$. ${ }^{19}$ Serta pernyataan dari sejumlah peneliti yang dipimpin Prof. Willem Takken dari Universtas Wageningem menyatakan alat perangkap bau badan manusia yang ditemukan terbukti efektif membasmi $70 \%$ populsi nyamuk Anopheles. ${ }^{20}$

Sesuai dengan hasil penelitian Hebert Adrianto, dkk pada 2014 bahwa ekstrak daun jeruk purut (Citrus histrix) memiliki toksisitas tertinggi dibandingkan spesies jeruk lainnya, sehingga daun jeruk purut mampu dijadikan formula terbaik untuk membuat insektisida yang efektif. ${ }^{5}$ Penurunan rata-rata kematian nyamuk terjadi pada berat $400 \mathrm{mg}$ yaitu menjadi 9 ekor dari 3 kali pengulangan. Penurunan ini dikarenakan kurangnya penguapan dari mat daun jeruk purut sehingga mempengaruhi jumlah aroma atau bau yangdikeluarkan dari anti nyamuk elektrik itu sendiri. Semakin tinggi berat daun jeruk purut yang digunakan, maka membutuhkan kadar air yang lebih banyak untuk prosespenguapan dan tingkat kepadatan mat. Perbandingan kadar air yang tidak sesuaidengan berat daun jeruk purut mempengaruhi penguapan aroma daun jeruk purut. Jika kadar airterlalu sedikit, maka serbuk daun tidak terkena air secara menyeluruh. Hal ini menyebabkan penguapan yang tidak optimal dari daun 
jeruk purut tersebut. Penguapan yang optimal juga didukung oleh jumlah panas yang berasal dari mesin elektrik. Berat daun jeruk purut yang berbeda-beda diasumsikan membutuhkan jumlah panas yang berbeda-beda juga. Semakin berat mat daun jeruk purut maka dibutuhkan jumlah panas yang semakin tinggi.

Senyawa flavonoid bekerja sebagai racun inhalasi dengan masuk ke dalam mulut serangga melalui saluran pencernaan berupa spirakel yang terdapat dipermukaan tubuh yang kemudian akan menimbulkan kelayuan pada saraf dan kerusakan pada spirakel, akibatnya serangga tidak bisa bernafas dan mati, ${ }^{10}$ sehingga daun jeruk purut dapat digolongkan sebagai insektisida racuninhalasi dan racun kontak.

Dinyatakan racun kontak apabila insektisida dapat masukkedalam tubuh nyamuk lewat kulit dan bersinggungan langsung (Djojosumarto,2000). Menurut cara kerjanya, daun jeruk purut juga dapat digolongkan sebagaiinsektisida racun saraf karena berdasarkan pengamatan yang dilakukan selamapercobaan, nyamuk Culex sp. mengalami perubahan sebelum dan sesudah dinyalakan anti nyamuk mat elektrik daun jeruk purut. Nyamuk Culex sp.dari yang bergerak sangat aktif berusaha keluar (karena aroma yang dikeluarkan mat daun jeruk purut) sampai pada akhirnya menjadi lamban dan lemas, dan kemudian lumpuh danmati. Hal ini juga tejadi pada penelitian Wiwiek, 2010 efektivitas ekstrak babandotan terhadap mortalitas nyamuk Aedesaegypti.

\section{Simpulan}

Rerata kematian nyamuk semakin tinggi sesuai dengan meningkatnya konsentrasi obat yang diberikan; dengan rerata kematian nyamuk tertinggi (15.00) terdapat pada konsentrasi $1.0 \mathrm{ml}$, terdapat perbedaan rerata kematian nyamuk yang signifikan pada masing-masing konsentrasi perasan daun jeruk purut, ada perbedaan tingkatan konsentrasi yang diujikan memberikan efek perbedaan rerata yang signifikan terhadap kematian nyamuk.

\section{Daftar Pustaka}

1. Yudhastuti, R dan Vidiyani, A 2005, Hubungan Kondisi Lingkungan, Kontainer \& Perilaku Masyarakat dengan Keberadaan Jentik Nyamuk Aedes aegypti diDaerah Endemis DBD Surabaya, Jurnal Kesehatan Lingkungan, Surabaya.

2. Susanna, D dan Sembiring, TU 2011, Entomologi Kesehatan (Antropoda Pengganggu

Kesehatan dan Parasit yang Dikandungnya), UI Press, Jakarta.

3. Kardinan, A 2004, Pestisida Nabati, Ramuan \& Aplikasi, Penebar Swadaya, Jakarta. 2005, Tanaman Pengusir \& Pembasmi Nyamuk, cetakan 5, Agro Media Pustaka, Jakarta

4. Qoriah.2010. Efektifitas model payung perangkap nyamuk dalam membunuh Aedes aegypti Di Laboratorium. Karya Tulis Ilmiah UMS.

5. Adrianto,Hebert,dkk.2014.Efektifitas Ekstrak Daun Jeruk Purut ( Citrus hystrix), Jeruk Limau (Citrus amblycarpa), dan Jeruk Bali (Citrus maxima) Terhadap Larva Aedes aegypti.JURNAL FK Universitas Airlangga

6. Jumar 2000, Entomologi Pertanian, Rineka Cipta, Jakarta 
7. Susanna, D dan Sembiring, TU 2011, Entomologi Kesehatan (AntropodaPengganggu Kesehatan dan Parasit yang Dikandungnya), UI Press, Jakarta.

8. Yudhastuti, R dan Vidiyani, A 2005, Hubungan Kondisi Lingkungan, Kontainer \&Perilaku Masyarakat dengan Keberadaan Jentik Nyamuk Aedes aegypti di Daerah Endemis DBD Surabaya, Jurnal Kesehatan Lingkungan, Surabaya.

9. Mulyani, S, dan Gunawan, D 2010, Ilmu Obat Alam (Farmakognosi), cetakan kedua,Penebar Swadaya, Jakarta.

10. Pane, AD 2009, Efektivitas Ekstrak Daun Pandan Wangi (Pandanus amarrilious) sebagai Insektisida terhadap Nyamuk Aedes, spp, Sripsi Fakultas Kesehatan Masyarakat Universitas Sumatera Utara.

11.Wiwiek, SS 2010, Efektivitas Ekstrak Daun Babandotan (Ageratum Conyzoides L) Terhadap Mortalitas Nyamuk Aedes Aegypti, Skripsi Fakultas Kesehatan Masyarat Universitas Sumatera Utara

12. Mardiana, S, dan Aminah, NS 2009,

Datura Metel Linnaeus sebagai Insektisida dan Larvasida Botani serta Bahan Baku Obat Tradisional, Media Peneliti danPengembangan Kesehatan, vol XIX.

13.Chaieb, I 2010 Saponins as insecticides: a review, Tunisian Journal of Plant Protection, Tuinisia.

14.Geyter, ED, Lambert E, Geelen, D, dan Smagghe, G 2007, Novel Advances with Plant Saponins as Natural Insectisides to Control Pest Insects, Journal of University of Belgium, Belgia.
15.Direktorat Jenderal Pengendalian Penyakit dan Penyehatan Lingkungan. Pedoman Penatalakasanaan Kasus Malaria Di Indonesia. Jakarta: Departemen Kesehatan RI;2008

16. Setyaningrum E, Rosa E, Murwani S, Andananta K. Studi Ekologi Perindukan Nyamuk Vektor Malaria Di Desa Way Muli, Kecamatan Rajabasa Lampung Selatan. Prosiding Seminar Hasil dan Pengabdian

Kepada Masyarakat Karya Peneliti Universitas Lampung. Lembaga Penelitian Universitas Lampung [internet]. 2008. [disitasi 10 November 2014]. Tersedia dari:http://blog.u.ac.id/enianitaq/files/2013/ 06/jurnal-Perindukan-Nyamuk-

\section{VektorMalaria.pdf}

17.Titik Lestari, 2016. Pemanfaatan Jeruk Purut Sebagai Biolarvasida. Kementerian Kesehatan Politeknik Kesehatan Surakarta Jurusan Jamu

18. Rahayu, nita, Sri sulasmi, Yuniarti Suryatinah. 2016. Eektivitas Aplikasi elambu Berinsektisida, Balitbangkes, Kalimantan Selatan

19.Zumrotus Sholichah, dkk. 2010.Efikasi insektisida barbahan aktif cypermetrin dengan metoda lethal ovitraf terhadap Aedes aegypti , J Jurnal Balaba Vol. 6, No. 02, Des 2010 : 7-11

20. Andriana, agustin, dkk, .2012. Uji nyamuk Aedes aegypti ekstrak buah kulit jeruk purut dan jeruk kalamonden sebagai biolarvasidaji efektivitas Aedes aegypti, Program Studi S1 Biologi, Departemen Biologi, Fakultas Sains dan 
Surabaya.

21.Istianah,, dkk . 2013. Efektivitas Biolarvasida Minyak Daun Jeruk Purut (Citrushystrix) Terhadap Larva Instar III Nyamuk Aedes aegypti.Jurusan Kedokteran, Fakultas Kedokteran, Universitas Jember (UNEJ)

22.Umiyan Kamarullah. 2015. Uji efektivitas daun jeruk purut sebagai biolarvasiada untuk membunuh vektor DBD (Demam Berdarah Dengue) larva nyamuk Aedes aegypti. Jurusan Kesehatan Masyarakat, Fakultas Ilmu-ilmu Kesehatan dan Keolahragaan, Universitas Negeri Gorontalo. 